\title{
Teaching and Learning Mathematics in Turkey
}

\author{
Huriye Arikan
}

This presentation discusses mathematics education in Turkey from the perspective of teaching and learning. An overview of mathematics education in Turkey, the contemporary national high school mathematics curriculum, its varied applications, and factors affecting its success are presented. The national exam, which is mandatory for all students to be admitted to a university in Turkey, destructively circumscribes the mathematics curriculum in high schools. In this context, the factors causing unfavorable outcomes and preventive measures are discussed. While a modest selection of national and international attributes of educators and agencies are provided, the presentation mainly focuses on the achievements of the Turkish Mathematical Society in enhancing mathematics education and promoting public interest in the subject. A narration of an innovative school, the Nesin Mathematical Village, which is designed to cultivate deep mathematics appreciation among its participants, is given.

\section{Introduction}

In three main parts, this national presentation discusses mathematics education in Turkey from the perspective of teaching and learning. The presentation consists of an overview of mathematics education in Turkey, the achievements of the Turkish Mathematical Society in enhancing mathematics education and promoting public interest in mathematics, and a showcase of a unique revolutionary act in mathematics education, the Nesin Mathematical Village. In this article a very brief

\footnotetext{
H. Arikan $(\bowtie)$

Sabancı University, Istanbul, Turkey

e-mail: huriye@sabanciuniv.edu 
summary of the talk in the scope of the national presentation along with some highlighted incidents in relation to the promotion of public interest in mathematics is provided. References are provided for further information.

\section{An Overall Summary of Mathematics Education in Turkey}

Education in Turkey is a state-supervised national system. Compulsory education, primary, secondary and high school lasts 12 years between the ages of 6 and 18 . Pre-primary education includes optional education of children between 36 and 72 months old. Education is financed by the state and free of charge in public schools and in state universities. Secondary or high school education is mandatory but required in order to progress to universities. The student selection and placement system for university is composed of two consecutive exams that are held once a year and are mandatory for all students to be admitted to a university in Turkey. There is severe competition among students who want to be admitted to one of the 146 universities or the open education university in the country. In 2011 the total capacity of universities was 450,000 while the number of candidates was 1.6 million and has been increasing every year. Last year, 2,255,386 high school graduates took the exam. The content of these exams and the subjects that are included or excluded destructively circumscribe the mathematics curriculum in high schools. Some basic subjects, such as volume of revolution, L'Hospital rule, modular arithmetic, matrices and determinants and inverse trigonometric functions are practically omitted from the mathematics curricula in most schools. The multiple-choice nature of the university entrance and placement exams also affects the students' cognition of mathematical concepts and restricts their ability to deduce, prove and express the mathematical results and solutions accurately in written form.

The difference between the curriculum of mathematics education at the high school level designed by the Ministry of National Education and the curricula used in private schools indicates gaps in educational levels among students. During the past years, a great deal of effort has been made, ambitious projects (RTI International \& ERI Initiative, 2013) have been utilized, and measures have been taken to improve mathematics education. As a result of the National Education Development Project initiated by Higher Education Council financed by the World Bank, after the 1990s most of the studies in mathematics education have been dominated by "cognitive dimensions" of mathematics, "curriculum studies" and "teaching methods" (Argün, 2008; Ayhan, 1998; Baki, 1997). In the last 10 years the budget allocated for education has dramatically increased. In-service training for all teachers at all levels has been provided by the Ministry of National Education and certificate programs for further degree completion and graduate study opportunities have been provided in cooperation with higher education institutions. Annual nationwide "Good Practice in Education Conferences" organized by the Education Reform Initiative of Sabanc1 University, brings teachers and instructors 
together to improve their learning, and the learning environment in class and in school. The Scientific and Technological Council of Turkey has substantially increased the allocated budget for projects related to mathematics education and in 2014, jointly with the Ministry of Education, implemented several financial support programs for successful students who have chosen to study mathematics at the undergraduate level. In spite of these efforts, the international and national reports, PISA (Ceylan, Yetişir, Yıldırım, \& Yıldırım, 2013) and TIMSS (Gönen, Parlak, Polat, Özgürlük, \& Yıldırım, 2016) results reveal the fact that the governmental incentives and support for maintaining an effective mathematics teaching environment in Turkey have not been enough. In this context the factors causing the unfavorable outcomes and preventive measures to counteract these outcomes (Oral \& McGiveney, 2013; Şirin \& Vatanartıran, 2014) were discussed further during the oral presentation.

Although higher education institutions had accommodated various degree programs in teacher training and research opportunities in education, until 1982 there were no faculties of education at universities in Turkey. In 1982, the Higher Education Council unified all higher education institutions in the country as universities; after this occurred, several universities established faculties of education that administratively separated the research mathematicians and mathematics educators. The National Educational Development Project restructured the schools of education between 1994 and 1998. In 1999, there were only 46 mathematics educators, including graduate students, located at several universities in the country (Askar \& Ubuz, 1999). Research studies in mathematics education were mainly conducted by university instructors. These studies mostly investigated cognitive and affective domains; subjects in geometry were widely studied and the main instruments were data collection using tests followed by a questionnaire. The number of publications in Turkish and in national journals seemed insufficient compared to the number of publications in international journals (Ubuz \& Ulutaş, 2008). In time, the number of mathematics educators has dramatically increased, and 63 state and 9 private universities out of 147 offer bachelor of science degree programs in mathematics education. Becoming a school teacher in mathematics requires a degree in education. Becoming a primary school mathematics teacher requires at least a bachelor's degree in mathematics education, while becoming a secondary or a high school teacher requires a minimum of a master's degree in mathematics education.

Contemporary research in mathematics education is advanced and the research environment is cultivated by national and international collaborative projects, platforms and conferences. Significant international conferences such as Psychology of Mathematics Education 2011 (PME35) and the Congress of Research in Mathematics Education 2013 (CERME8) have taken place in Turkey.

The Turkish Mathematical Society, the Mathematicians Association and the Mathematics Education Association are the three foremost non-governmental organizations supporting the enhancement of national mathematics education in Turkey. These institutions all contribute by organizing annual international and national conferences, workshops and project contests. 


\section{Achievements of the Turkish Mathematical Society}

The Turkish Mathematical Society was founded in 1948 and is a member of the International Mathematical Union and the European Mathematical Society. The society supports the advancement of mathematics, mathematical sciences and related disciplines and promotes mathematics education and the exposition of mathematics at all levels through appropriate venues. Membership is open to all who use mathematics in their vocations. In addition to annual national and international conferences the society provides monthly talks on popular mathematics subjects.

The Friends of Mathematical Research (MAD) campaign society raises money to support young researchers, prominent research activities, international and national workshops, and seminars. The quarterly popular magazine Matematik Dünyası (The World of Mathematics) has a high circulation. The large-scale International Conference in Teaching of Mathematics at the undergraduate level; ICTM3), which has the aim of bringing mathematicians and math educators together, was organized by the Society in 2006 (Kyle, 2006). The interactive mathematics exhibition "IMAGINARY" visited Turkey as a joint project of the Mathematical Research Institute Oberwolfach, the Turkish Mathematical Society and the Istanbul Center for Mathematical Sciences. There has been a great interest in exhibitions in İstanbul, İzmir, Diyarbakır, Adana, Ankara, and other cities. The profound mathematician Cahit Arf's photograph adorns the 10 Turkish Lira banknotes along with his formula, Arf's invariant, making mathematics a part of the national cultural surplus.

\section{A Dream School: Nesin Mathematical Village}

Nesin Mathematical Village is a revolutionary and unique act, forming a mathematical community located at an unexpected place in the world and achieving unexpected success. The Nesin Mathematics Village was established in 2007 by a remarkable mathematics researcher, Ali Nesin (Alladi \& Rino Nesin, 2015). The project was inspired by the realization that students needed an outlet that was alternative to traditional methods of mathematics teaching and involved learning mathematics outside the classroom through group work and mutual interaction (Karaali, 2014). Currently the village offers over 140 different courses at high school, undergraduate and graduate levels and has more than 1500 students per year. The village provides community life to help educate and encourage students to research and facilitate the exchange of mathematical information between adults and children. Participants enjoy various mathematics classes, and have the opportunity to attend seminars and lectures by renowned mathematicians, economists and intellectuals. The village is the realization of a dream school where students and teachers cook and clean together and young students learn to take responsibility, to share, and not to fear mathematics. The village has served as a good example and similar projects are under construction. 


\section{References}

Alladi, K., \& Rino Nesin, G. A. (2015). The Nesin mathematics village in Turkey. Notices of the AMS, 62(6), 652-685.

Argün, Z. (2008). Lise matematik öğretmenlerin yetiştirilmesinde mevcut yargılar, yeni fikirler. TÜBAV Bilim Dergisi, 1(2), 88-94.

Așkar, P., \& Ubuz, B. (1999). Current state of the mathematics education community in Turkey. Hacettepe Üniversitesi Ë̆itim Fakültesi Dergisi, 15(15).

Aydın, A. (1998). Eğitim fakültelerinin yeniden yapılandırılması ve öğretmen yetiștirme sorunu. Kuram ve Uygulamada Egitim Yönetimi Dergisi, 4(3), 275-286.

Baki, A. (1997). Çağdaş Gelişmelerin Işı̆̆ında Matematik Öğretmenliği Eğitim Programları. Eğitim ve Bilim, 21(103).

Ceylan, E., Yetișir, M. İ., Yıldırım, H. H., Yıldırım, S. (2013). PISA 2012 Ulusal Ön Raporu. Republic of Turkey Ministry of National Education. http://pisa.meb.gov.tr/wp-content/uploads/ 2013/12/pisa2012-ulusal-on-raporu.pdf. Accessed: December 12, 2016.

Gönen, E., Parlak, B., Polat, M., Özgürlük, B., \& Yıldırım, A. (2016). TIMSS 2015 Ulusal Matematik ve Fen Ön Raporu 4. Ve 8. Siniflar. Resource document. Republic of Turkey Ministry of National Education. http://timss.meb.gov.tr/wp-content/uploads/Timss_2015_ ulusal_fen_mat_raporu.pdf. Accessed: December 12, 2016.

Kyle, J. (2006). The third international conference on the teaching of mathematics. MSOR Connections, Vol. 6 No 3 August-October 20, 2006. https://www.heacademy.ac.uk/system/ files/msor.6.3r.pdf. Accessed: December 12, 2016.

Karaali, G. (2014). Nesin math village: Mathematics as a revolutionary act. The Mathematical Intelligencer, 36(2), 45-49.

Oral, I., \& McGiveney, E. (2013). Student performance in math and science in Turkey and determinants of success TIMSS 2011 analysis. Resource Document. Education Reform Initiative (ERG), Istanbul Policy Center (IPC), Sabanc1 University. http://www. egitimreformugirisimi.org/sites/www.egitimreformugirisimi.org/files/TIMSS\%20abstract\% 20summary.pdf. Accessed: December 12, 2016.

RTI International, \& Education Reform Initiative (ERI). (2013). Turkey's FATIH project: A plan to conquer the digital divide or a technological leap of faith? http://www.rti.org/sites/default/ files/resources/fatih_report_eri-rti_dec13.pdf. Accessed: December 12, 2016.

Şirin, R. S., \& Vatanartıran, S. (2014). PISA 2012 evaluation: Data based education reform proposals for Turkey, Turkish Industry. \& Business Association (TUSIAD) - All Private Education Institutions Association (TÖDER), TÜSİAD-T/2014-02/549. ISBN: 978-9944-405-98-0.

Ubuz, B., \& Ulutaș, F. (2008). Research and trends in mathematics education: 2000 to 2006. Elementary Education Online, 7(3), 614-626.

Open Access Except where otherwise noted, this chapter is licensed under a Creative Commons Attribution 4.0 International License. To view a copy of this license, visit http://creativecommons. org/licenses/by/4.0/.

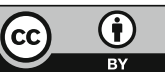

